\title{
KEMAMPUAN BERPIKIR KREATIF SISWA SMP KELAS VIII PADA MATERI SISTEM PERSAMAAN LINEAR DUA VARIABEL MELALUI PENDEKATAN OPEN ENDED
}

\author{
Inggri Anggraeni ${ }^{1}$, Heris Hendriana ${ }^{2}$, Luvy Silviana Zanthy ${ }^{3}$ \\ 1,23 IKIP Siliwangi, Jl. Terusan Jendral Sudirman, Cimahi \\ ${ }^{1}$ inggrianggraeni2508@gmail.com, ${ }^{2}$ herishen@ikipsiliwangi.ac.id, \\ ${ }^{3}$ zanthyluvy@ikipsiliwangi.ac.id
}

\begin{abstract}
This study aims to examine the improvement of student's creative thinking ability of Class VIII on the material of two-variable linear equation system through open ended approach. This type of research is classroom action research. The method of this research is qualitative descriptive. This research was conducted on grade VIII-C student of SMP Darul Falah in the academic year 2017/2018 with 36 student. The instrument used in a student's mathematical creative thinking test, cycle I and II test (after giving of action), and an observation sheet for teachers and students to conditions of action implementation. The result of this study indicate that the aspect of matehematical thinking creative ability of students has increased because of the problems tested in each test, the more students who score above the KKM. Based on the work indicator, it is concluded that the mathematical creative thinking ability of grade VIII-C students of SMP Darul Falah on two-variable linear equation system can be improved through open ended approach.
\end{abstract}

Keyword: creative thinking, two-variable equation system, open ended

\begin{abstract}
Abstrak
Penelitian ini bertujuan untuk menelaah peningkatan kemampuan berpikir kreatif siswa kelas VIII pada materi sistem persamaan linear dua variabel melalui pendekatan open ended. Jenis penelitian ini adalah penelitian tindakan kelas. Metode penelitian ini adalah kualitatif deskriptif. Penelitian ini dilaksanakan pada siswa kelas VIII-C SMP Darul Falah tahun pelajaran 2017/2018 dengan jumlah siswa 36 orang. Instrumen yang digunakan adalah tes kemampuas berpikir kreatif matematis siswa, tes siklus I dan II (setelah pemberian tindakan), dan lembar observasi bagi guru dan siswa untuk kondisi pelaksanaan tindakan. Hasil penelitian ini menunjukkan bahwa aspek kemampuan berpikir kreatif matematis siswa mengalami peningkatan karena dari soal yang diujikan dalam setiap tes, semakin banyak siswa yang memperoleh nilai di atas KKM. Berdasarkan indikator kerja, disimpulkan bahwa kemampuan berpikir kreatif matematis siswa kelas VIII-C SMP Darul Falah pada materi sistem persamaan linear dua variabel dapat ditingkatkan melalui pendekatan open ended.
\end{abstract}

Kata kunci: berpikir kreatif, sistem persamaan linear dua variabel, open ended

How to cite: Anggraeni, I., Hendriana, H., \& Zanthy, L. S. (2018). Kemampuan Berpikir Kreatif Siswa SMP Kelas VIII pada Materi Sistem Persamaan Linear Dua Variabel melalui Pendekatan Open Ended. JPMI - Jurnal Pembelajaran Matematika Inovatif, 1 (5), 903-914

\section{PENDAHULUAN}

Berpikir kreatif bukanlah hal baru dalam matematika, sebab para matematikawan terdahulu seperti Plato, Euclid, atau Mandelbrot (Hendriana, 2014) telah mengaitkan matematika dengan keindahan, kreativitas, atau imajinasi dalam matematika. Kemampuan berpikir kreatif 
merupakan kebutuhan yang harus dimiliki di era globalisasi. Hal ini didukung oleh pernyataan Sumarmo (Istianah, 2013) pentingnya keterampilan kreatif dilatihkan kepada siswa, didukung oleh visi pendidikan matematika yang mempunyai dua arah pengembangan, yaitu memenuhi kebutuhan masa kini dan masa yang akan datang. Berpikir kretaif juga berhubungan erta dengan penalaran hal ini uangkapkan oleh Hidayat, Heridman, Aripin, Yuliani \& Maya (2018) penalaran kreatif merupakan proses berpikir seseorang dalam memecahkan permasalahan dengan cara yang meliputi kebaruan, masuk akal dan berdasar matematis.

Terlihat bahwa berpikir kreatif memiliki peran penting dalam pembelajaran matematika, sehingga berpikir kreatif merupakan kemampuan yang perlu diperhatikan. Namun dalam kenyataan di lapangan, kemampuan berpikir kreatif matematis terutama pada siswa SMP masih tergolong rendah. Seperti halnya yang terjadi di kelas VIII-C SMP Darul Falah. Pada studi awal yang dilakukan di sekolah tersebut tepatnya 22 November 2017, diperoleh informasi dari guru matematika bahwa dalam proses pembelajaran matematika masih banyak ditemui beberapa permasalahan, diantaranya guru kesulitan dalam menerapkan pendekatan pembelajaran yang tepat, sehingga mengakibatkan siswa tidak mampu menerima pengetahuan matematika yang baik sehingga penguasaan materi sistem persamaan linear dua variabel siswa masih kurang. Hal ini sejalan dengan pendapat Syah, M. (Zanthy, 2018) Faktor yang mempengaruhi menurunnya prestasi akademik adalah: 1) faktor internal yaitu faktor yang berasal dari dalam mahasiswa itu sendiri, yaitu faktor fisiologis dan faktor psikologis; 2) faktor eksternal, yaitu faktor yang berasal dari luar diri mahasiswa, contohnya: kurikulum, guru, metode, dll.

Berdasarkan permasalahan di atas, kemudian muncul pertanyaan pendekatan apa yang dapat mengasah kemampuan berpikir kreatif siswa dalam menyelesaikan permasalahan, melibatkan aktivitas siswa secara optimal, dan membuat pembelajaran matematika menjadi lebih aktif dan menyenangkan. Menurut Getzels dan Jackson (Ristiani, Ratu, \& Prihatnami, 2014) salah satu cara untuk mengukur kemampuan berpikir kreatif, yakni dengan masalah terbuka. Salah satu alternatif pembelajaran yang dirancang sedemikian rupa sehingga dapat melatih berpikir kreatif dan mencerminkan siswa secara aktif serta pembelajaran bermakna adalah pembelajaran matematika dengan pendekatan open ended. Shimada (Afandi, 2013) menyatakan bahwa pendekatan open ended adalah pendekatan pembelajaran yang menyajikan suatu permasalahan yang memiliki penyelesaian yang benar lebih dari satu teknik. Sadangkan Nohda (Setiawan \& Harta, 2014) berpendapat bahwa pendekatan open ended sangat penting bagi setiap siswa untuk memiliki kebebasan dalam meningkatkan kemampuan pemecahan masalah sesuai dengan tingkat kemampuan dan minat mereka.

Berdasarkan masalah dan solusi pendekatan yang ada, peneliti akan mengambil sebuah judul "Kemampuan Berpikir Kreatif Siswa SMP pada Materi Sistem Persamaan Linear Dua Variabel dengan Pendekatan Open Ended". Tujuan penelitian ini yaitu untuk menelaah peningkatan kemampuan berpikir kreatif siswa kelas VIII pada materi sistem persamaan linear dua variabel melalui pendekatan open ended.

\section{METODE}

Jenis penelitian ini adalah penelitian tindakan kelas. Menurut Arikunto (Karneli, Ananta, \& Hapsari, 2015) Penelitian tindakan kelas merupakan suatu pencermatan terhadap kegiatan yang sengaja dimunculkan, dan terjadi dalam sebuah kelas. Metode yang digunakan adalah 
kualitatif deskriptif yang bertujuan untuk mendeskripsikan aktivitas guru dan siswa ketika dalam pembelajaran dan menelaah kemampuan berpikir kreatif siswa setelah melaksanakan pembelajaran dengan menggunakan pendekatan open ended. Penelitian tindakan kelas ini terdiri dari dua siklus. Sampel penelitiannya siswa kelas VIII-C dengan jumlah siswa 36 orang di SMP Darul Falah Cihampelas Kabupaten Bandung Barat tahun akademik 2017-2018. Sebelum dilaksanakan tindakan, terlebih dahulu diberikan tes awal untuk mengetahui kemampuan awal siswa dan berkaitan dengan topik yang akan diajarkan yaitu sistem persamaan linear dua variabel.

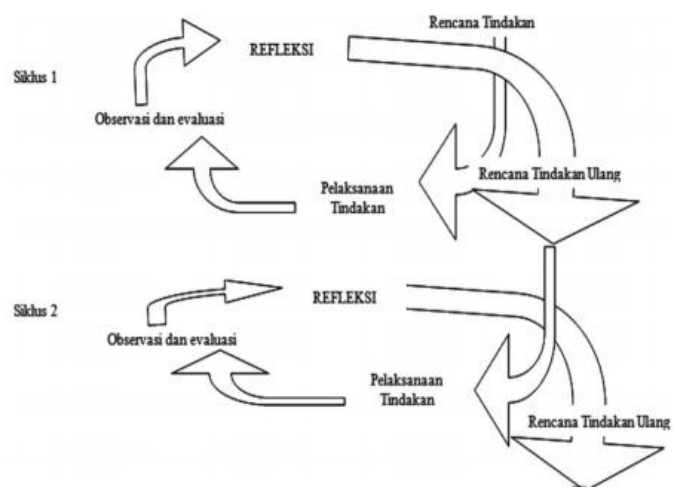

Gambar 1. PTK Model Gabungan Sanford dan Kemmis

(Taniredja, Pujiati, \& Nyata, 2010)

Indikator keberhasilan peningkatan kemampuan berpikir kreatif matematika siswa pada penelitian ini merujuk pada:

1. Adanya pencapaian ketuntasan belajar minimal $70 \%$ dari jumlah seluruh siswa dan perolehan nilai minimal 7,00 secara perorangan.

2. Proses pelaksanaan pembelajaran berhasil apabila tindakan guru dan siswa mencapai $75 \%$ sesuai dengan rencana pelaksanaan pembelajaran.

\section{HASIL DAN PEMBAHASAN}

\section{Hasil}

\section{Tindakan Siklus I}

\section{Rencana Tindakan}

Pada tahap ini, hal-hal yang harus dilakukan adalah membuat rencana pelaksanaan pembelajaran (RPP) berdasarkan silabus yang menjadi acuan penelitian. RPP yang dibuat untuk siklus I terdiri dari dua pertemuan pada materi " sistem persamaan linear dua variabel", dengan menggunakan pendekatan open ended. Setelah itu, membentuk kelompok siswa. Karena jumlah siswa kelas VIII-C SMP Darul Falah sebanyak 36 orang, maka kelompok yang dibentuk sebanyak 9 kelompok yang heterogen. Kemudian peneliti membuat lembar observasi untuk guru dan siswa, menyiapkan LKS, merancang perangkat evaluasi untuk tes siklus I.

\section{Pelaksanaan Tindakan}

Tindakan pembelajaran siklus I dilaksanakan dalam dua kali pertemuan yaitu pada hari Rabu 22 November 2017 pada pukul 7.20-8.40 WIB dan hari Jum'at 24 November 2017 pukul 
10.15-11.25 WIB. Pembelajaran diawali dengan guru menyampaikan tujuan dan manfaat pembelajaran, kemudian mengecek kesiapan belajar siswa. Pada kegiatan inti, guru membagikan LKS pada setiap kelompok. Guru berkeliling untuk membimbing jalannya diskusi. Setelah menyelesaikan soal tersebut, setiap kelompok berkesempatan untuk mempresentasikan hasil diskusi. Ketika salah satu kelompok sedang presentasi, guru menunjuk salah seorang siswa untuk menyelesaikan masalah dalam LKS. Namun, siswa tersebut tidak dapat memberikan penyelesaian yang sesuai dengan tujuan pembelajaran.

Hal tersebut menunjukkan bahwa kemampuan berpikir kreatif siswa pada materi persamaan linear dua variabel dalam menyelesaikan masalah belum optimal tercapai, namun hal tersebut dibantu oleh teman kelompoknya untuk menyelesaikan masalah tersebut.

Pada akhir pembelajaran, guru membimbing siswa menyimpulkan materi yang telah dipelajari. Kemudian, guru memberikan tes evaluasi siklus I sebanyak 5 soal dan waktu mengerjakannya 30 menit. Setelah itu, guru menutup pembelajaran dengan doa. Setelah penyajian kelas kedua ini, guru dan peneliti mendiskusikan kekurangan yang terjadi dalam pembelajaran. peneliti menyarankan agar ke-lima komponen utama dalam pendekatan open ended dioptimalkan kembali pada siklus selanjutnya.

\section{Observasi dan Evaluasi}

Pada tahap ini peneliti mengobservasi setiap pelaksanaan proses pembelajaran selama siklus I menggunakan lembar observasi. Hal-hal yang diobservasi meliputi cara guru dalam menyampaikan materi pelajaran yang sesuai dengan pendekatan pembelajaran open ended dan sikap siswa selama mengikuti pelajaran, keaktifan siswa selama diskusi kelompok, kemampuan siswa menemukan penyelesaian masalah tersebut, keberanian bertanya dan menyampaikan pendapat. Hasil observasi terhadap siswa dan guru pada dua pertemuan dapat diuraikan sebagai berikut:

1) Guru tidak melakukan apersepsi pada kegiatan awal pembelajaran.

2) Guru kurang dapat menguasai kelas dan mengontrol siswa dalam kegiatan kelompok.

3) Guru kurang tegas dalam mengatur siswa yang tidak bersungguh-sungguh mengikuti pembelajaran.

4) Guru kurang memberikan motivasi.

Guru tidak memberikan PR.

Tabel 1. Hasil Analisis Observasi Aktivitas Guru pada Pembelajaran Siklus I

\begin{tabular}{|c|c|c|c|c|}
\hline \multirow[b]{2}{*}{$\begin{array}{l}\mathbf{N} \\
\mathbf{0}\end{array}$} & \multirow[b]{2}{*}{ Aspek } & \multicolumn{2}{|c|}{ Hasil Skor } & \multirow[b]{2}{*}{$\begin{array}{l}\text { Rata- } \\
\text { rata }\end{array}$} \\
\hline & & $\begin{array}{c}\text { Pertemuan } \\
\text { I }\end{array}$ & $\begin{array}{c}\text { Pertemuan } \\
2\end{array}$ & \\
\hline \multicolumn{5}{|c|}{ Pendahuluan } \\
\hline 1 & Guru menyampaikan tujuan pembelajaran & 3 & 4 & 3,5 \\
\hline 2 & Guru melakukan apersepsi & 3 & 2 & 2,5 \\
\hline 3 & Guru memotivasi siswa & 3 & 2 & 2,5 \\
\hline 4 & Guru mengondisikan siswa untuk siap belajar & 2 & 3 & 2,5 \\
\hline & \multicolumn{4}{|c|}{ Kegiatan Inti } \\
\hline 5 & $\begin{array}{l}\text { Guru membagi siswa dalam beberapa } \\
\text { kelompok }\end{array}$ & 5 & 5 & 5 \\
\hline 6 & Guru membagikan LKS kepada masing- & 5 & 5 & 5 \\
\hline
\end{tabular}




\begin{tabular}{llccc}
\hline & masing kelompok & & \\
\hline 7 & $\begin{array}{l}\text { Guru membimbing siswa dalam mengerjakan } \\
\text { LKS }\end{array}$ & 3 & 3,5 \\
\hline 8 & $\begin{array}{l}\text { Guru meminta setiap kelompok untuk } \\
\text { presentasikan hasil diskusi }\end{array}$ & 3 & 3 & 2,5 \\
\hline 9 & $\begin{array}{l}\text { guru mencatat respon siswa menurut hasil } \\
\text { diskusi }\end{array}$ & 2 & 3 & 3 \\
\hline 1 & $\begin{array}{l}\text { Guru memberikan reward kepada kelompok } \\
\text { yang memberikan banyak strategi } \\
\text { penyelesaian. }\end{array}$ & 3 & 3 \\
\hline $\begin{array}{l}\text { Guru membimbing siswa untuk Kegiatan Penutup } \\
\text { menyimpulkan materi yang telah dipelajari }\end{array}$ & 3 & 0 \\
\hline $\begin{array}{l}\text { Guru memberikan tugas rumah dan } \\
\text { mengarahkan siswa untuk menyelesaikan } \\
\text { soal berdasarkan langkah-langkah yang telah } \\
\text { dipelajari. }\end{array}$ & 0 & 0 \\
\hline
\end{tabular}

Berdasarkan tabel 1, ketuntasan hasil observasi aktivitas guru pada proses pembelajaran mencapai $65 \%$. Hal ini menunjukkan bahwa indikator kerja dari segi proses belum tercapai yaitu minimal $75 \%$ proses pelaksanaan tindakan dilaksanakan sesuai dengan rencana pelaksanaan pembelajaran sehingga perbaikan diperlukan pada siklus berikutnya. Sementara itu, hasil observasi terhadap aktivitas siswa menunjukkan hal-hal sebagai berikut:

1) Tidak semua siswa memperhatikan guru Siswa masih kurang dapat bekerjas secara tim.

2) Interaksi siswa dan siswa masih rendah dalam menyelesaikan tugas bersama

3) Siswa dalam kelompok dapat menyelesaikan soal dengan beragam strategi, tetapi siswa dalam kelompok lain masih belum bisa menyelesaikan soal dengan beragam strategi.

Tabel 2. Hasil Analisis Observasi Aktivitas Siswa pada Pembelajaran Siklus I

\begin{tabular}{lllll}
\hline No & Aspek yang Dinilai & Hasil Skor & & Rata \\
\cline { 2 - 4 } & Pertemuan 1 & Pertemuan 2 & -rata \\
\hline 1 & $\begin{array}{l}\text { Siswa mendengarkan dan memberikan } \\
\text { perhatian penuh pada penjelasan materi } \\
\text { dan tujuan pembelajaran }\end{array}$ & 3 & 3 & 3 \\
\hline 2 & $\begin{array}{l}\text { Siswa memperhatikan guru dalam } \\
\text { memberikan motivasi. }\end{array}$ & 3 & 3 & 3 \\
\hline 3 & $\begin{array}{l}\text { Siswa aktif memberikan respon dalam } \\
\text { kegiatan apersepsi }\end{array}$ & 3 & 4 & 3,5 \\
\hline 4 & $\begin{array}{l}\text { Siswa aktif dalam kelompok ketika } \\
\text { menyelesaikan soal LKS }\end{array}$ & 2 & 3 & 2,5 \\
\hline 5 & Beberapa siswa senang belajar kelompok & 3 & 3 & 3 \\
\hline
\end{tabular}




\begin{tabular}{lllll}
\hline 6 & $\begin{array}{l}\text { Siswa mampu mengungkapkan } \\
\text { pemikiran tentang materi yang yang } \\
\text { dipelajari. }\end{array}$ & 2 & 2 \\
\hline 7 & $\begin{array}{l}\text { Siswa dalam kelompok mampu } \\
\text { mempresentasikan hasil diskusi di depan } \\
\text { kelas }\end{array}$ & 3 & 3 & 3 \\
\hline 8 & $\begin{array}{l}\text { Siswa di kelompok lain aktif menanggapi } \\
\text { hasil pekerjaan temannya }\end{array}$ & 2 & 3 & 2,5 \\
\hline 9 & $\begin{array}{l}\text { Siswa mampu bertanya ketika mendapat } \\
\text { kesulitan }\end{array}$ & 3 & 4 & 4 \\
\hline 10 & $\begin{array}{l}\text { Dengan bimbingan guru, siswa } \\
\text { menyimpulkan pembelajaran }\end{array}$ & 4 & $\mathbf{2 9 , 5}$ \\
\hline Jumlah & & & $\mathbf{5 9 \%}$ \\
\hline Presentase & & & 3 \\
\hline
\end{tabular}

Berdasarkan tabel 2, ketuntasan hasil observasi aktivitas siswa pada proses pembelajaran mencapai 59\%. Hal ini menunjukkan bahwa indikator kerja dari segi proses belum tercapai yaitu minimal $75 \%$ proses pelaksanaan tindakan dilaksanakan sesuai rencana pelaksanaan pembelajaran yang ditetapkan sehingga perlu dilakukan perbaikan pada siklus berikutnya.

Setelah 2 kali pertemuan untuk menyelesaikan kompetensi dasar "Menyelesaikan persamaan linear dua variabel", dilaksanakan evaluasi tindakan siklus I pada tanggal 22 dan 24 November 2017. Kegiatan ini dilakukan dengan tujuan untuk melihat sejauh mana materi pelajaran telah dikuasai siswa dan untuk melihat ketuntasan siswa dalam mengikuti pembelajaran matematika.

Tabel 3. Hasil Analisis Ketuntasan Belajar pada Pembelajaran Siklus I

\begin{tabular}{cccc}
\hline No & Ketuntasan & Jumlah & Presentase \\
\hline 1 & Tuntas & 20 & $55,5 \%$ \\
\hline 2 & Tidak tuntas & 16 & $44,5 \%$
\end{tabular}

Berdasarkan tabel 3, ketuntasan hasil belajar siswa pada proses pembelajaran mencapai $55,5 \%$. Hal ini menunjukkan bahwa pencapaian ketuntasan belajar siswa belum tercapai yaitu minimal $75 \%$ dari jumlah seluruh siswa dan perolehan nilai minimal 7,00 secara perorangan sehingga perlu dilakukan perbaikan pada siklus berikutnya.

\section{Refleksi}

Pada tahap ini, peneliti bersama guru dan pengamat menilai dan mendiskusikan kekurangan yang terdapat pada pelaksanaan tes siklus I yang akan diperbaiki pada siklus II. Pada siklus I ini, penerapan pembelajaran menggunakan pendekatan open ended masih belum optimal. Mengingat masih ada kekurangan yang terjadi pada pelaksanaan tindakan dan hasil belajar matematika pada evaluasi siklus I yang belum memenuhi indikator keberhasilan, maka penelitian dilanjutkan pada tindakan siklus berikutnya dalam upaya meningkatkan hasil belajar dilihat dari kemampuan berpikir kreatif siswa kelas VIII-C SMP Darul Falah melalui pendekatan pembelajaran open ended.

\section{Tindakan Siklus II}

\section{Rencana Pelaksanaan}


Berdasarkan hasil observasi, evaluasi dan refleksi pada tindakan siklus I, maka peneliti bersama guru merencanakan tindakan siklus II, agar kekurangan dan kelemahan yang terjadi pada siklus I tidak terulang lagi dan pelaksanaan pembelajaran semakin maksimal.

Oleh karena itu, pada tahap perencanaan ini peneliti berkolaborasi dengan guru melakukan hal sebagai berikut:

1) Membuat rencana perbaikan pembelajaran (RPP) untuk tindakan siklus II.

2) Membuat lembar observasi yang ditujukan pada guru dan siswa (aspek yang diobservasi didasarkan pada langkah-langkah pembelajaran pada RPP). Lembar observasi ini nantinya akan digunakan untuk memantau/mengamati kegiatan guru dan siswa selama proses pembelajaran berlangsung.

3) Menyiapkan perangkat evaluasi untuk evaluasi tindakan siklus II.

\section{Pelaksanaan Tindakan}

Pelaksanaan tindakan siklus II terdiri dari dua pertemuan. Peneliti tetap bertindak sebagai pengajar sedangkan Guru bertindak sebagai pengamat (observer). Tindakan pembelajaran siklus II dilaksanakan dalam dua kali pertemuan yaitu pada hari yang sama yaitu hari Rabu tanggal 29 November 2017 dan Jum'at tanggal 1 Desember pukul 7.20-8.40 WIB dan hari Jum'at 24 November 2017 pukul 10.15-11.25 WIB.

Pembelajaran diawali dengan menyampaikan tujuan pembelajaran dan manfaat mempelajari cara menyelesaikan sistem persamaan linear dua variabel. Kemudian guru mengondisikan kesiapan belajar siswa, mengadakan apersepsi atau mengulang pembelajaran pada pertemuan pertama yaitu pengertian persamaan linear dua variabel dan sistem persamaan linear dua variabel.

Pada kegiatan inti siswa duduk berkelompok, kemudian guru membagikan LKS pada setiap kelompok. Setelah itu, mengarahkan dan membimbing siswa dalam menyelesaikan LKS yang telah diberikan. Guru meminta perwakilan setiap kelompoknya mempresentasikan hasil kerjanya. Guru melihat siswa sudah dapat menyimpulkan suatu permasalahan, kemudian guru bertanya kepada siswa mengenai pendekatan open ended yang dilakukan dalam pembelajaran. Kebanyakan siswa menjawab pembelajaran open ended dapat memudahkan siswa memahami materi pembelajaran dengan cara menemukan banyak alternatif penyelesaian. Di akhir pembelajaran guru bersama siswa menyimpulkan materi yang telah dipelajari. Selama proses pembelajaran berlangsung, pengamat mengobservasi jalannya pembelajaran dengan menggunakan lembar observasi untuk guru dan siswa.

\section{Observasi dan Evaluasi}

Hasil observasi terhadap guru dan siswa ditunjukkan pada tabel berikut ini:

Tabel 4. Hasil Analisis Observasi Aktivitas Guru pada Pembelajaran Siklus II

\begin{tabular}{|c|c|c|c|c|}
\hline \multirow[b]{2}{*}{ No } & \multirow[b]{2}{*}{ Aspek } & \multicolumn{2}{|c|}{ Hasil Skor } & \multirow{2}{*}{$\begin{array}{l}\text { Rata- } \\
\text { rata }\end{array}$} \\
\hline & & $\begin{array}{c}\text { Pertemuan } \\
\text { I }\end{array}$ & $\begin{array}{c}\text { Pertemuan } \\
2 \\
\end{array}$ & \\
\hline \multicolumn{5}{|c|}{ Pendahuluan } \\
\hline 1 & $\begin{array}{l}\text { Guru menyampaikan } \\
\text { pembelajaran }\end{array}$ & 4 & 5 & 4,5 \\
\hline 2 & Guru memotivasi siswa & 4 & 4 & 4 \\
\hline 3 & Guru mengadakan apersepsi & 4 & 5 & 4,5 \\
\hline
\end{tabular}




\begin{tabular}{|c|c|c|c|c|}
\hline 4 & $\begin{array}{l}\text { Guru mengondisikan siswa untuk siap } \\
\text { belajar }\end{array}$ & 5 & 5 & 5 \\
\hline & \multicolumn{4}{|c|}{ Kegiatan Inti } \\
\hline 5 & $\begin{array}{l}\text { Guru membagi siswa dalam beberapa } \\
\text { kelompok }\end{array}$ & 4 & 5 & 4,5 \\
\hline 6 & $\begin{array}{l}\text { Guru membagikan LKS kepada } \\
\text { masing-masing kelompok }\end{array}$ & 5 & 5 & 5 \\
\hline 7 & $\begin{array}{l}\text { Guru membimbing siswa dalam } \\
\text { mengerjakan LKS }\end{array}$ & 4 & 5 & 4,5 \\
\hline 8 & $\begin{array}{l}\text { Guru meminta perwakilan kelompok } \\
\text { untuk presentasikan hasil diskusi }\end{array}$ & 4 & 5 & 4,5 \\
\hline 9 & $\begin{array}{l}\text { guru mencatat respon siswa menurut } \\
\text { hasil diskusi }\end{array}$ & 5 & 5 & 5 \\
\hline \multirow[t]{3}{*}{10} & Guru memberikan reward kepada & & & \\
\hline & $\begin{array}{l}\text { kelompok yang memberikan banyak } \\
\text { strategi penyelesaian. }\end{array}$ & 4 & 4 & 4 \\
\hline & \multicolumn{4}{|c|}{ Kegiatan Penutup } \\
\hline 11 & $\begin{array}{l}\text { Guru membimbing siswa untuk } \\
\text { menyimpulkan materi yang telah } \\
\text { dipelajari }\end{array}$ & 4 & 5 & 4,5 \\
\hline 12 & $\begin{array}{l}\text { Guru memberikan tugas rumah dan } \\
\text { mengarahkan siswa untuk } \\
\text { menyelesaikan soal berdasarkan } \\
\text { langkah-langkah yang telah dipelajari. }\end{array}$ & 4 & 4 & 4 \\
\hline & Jumlah & & & 54 \\
\hline & Presentase & & & $90 \%$ \\
\hline
\end{tabular}

Berdasarkan tabel 4, ketuntasan hasil observasi aktivitas guru pada proses pembelajaran mencapai 90\%. Hasil observasi kemampuan guru mengelola pembelajaran ini meningkat sebesar $25 \%$ dari siklus I. Hal ini menunjukkan bahwa indikator kerja dari segi proses sudah tercapai yaitu minimal $75 \%$. Sementara itu, hasil observasi terhadap siswa menunjukkan halhal sebagai berikut:

1) Siswa sudah mampu bekerja secara berkelompok.

2) Siswa dalam kelompok mampu mengikuti pembelajaran dengan baik dan menyenangkan.

3) Kepercayaan diri siswa dalam belajar meningkat.

4) Siswa senang belajar dalam kelompok dan berperan aktif dalam menyelesaikan soal.

Tabel 5. Hasil Analisis Observasi Aktivitas Siswa pada Pembelajaran Siklus II

\begin{tabular}{|c|c|c|c|c|}
\hline \multirow[b]{2}{*}{ No } & \multirow[b]{2}{*}{ Aspek yang Dinilai } & \multicolumn{2}{|c|}{ Hasil Skor } & \multirow[b]{2}{*}{$\begin{array}{l}\text { Rata- } \\
\text { rata }\end{array}$} \\
\hline & & $\begin{array}{c}\text { Pertemuan } \\
1\end{array}$ & $\begin{array}{l}\text { Pertemuan } \\
\quad 2\end{array}$ & \\
\hline 1 & $\begin{array}{l}\text { Siswa mendengarkan dan memberikan } \\
\text { perhatian penuh pada penjelasan materi dan } \\
\text { tujuan pembelajaran }\end{array}$ & 5 & 5 & 5 \\
\hline 2 & $\begin{array}{l}\text { Siswa memperhatikan guru dalam } \\
\text { memberikan motivasi. }\end{array}$ & 5 & 5 & 5 \\
\hline 3 & Siswa aktif memberikan respon dalam & 4 & 5 & 4,5 \\
\hline
\end{tabular}




\begin{tabular}{clcccc}
\hline \multicolumn{2}{l}{ kegiatan apersepsi } & & & \\
\hline 4 & $\begin{array}{l}\text { Siswa aktif dalam kelompok ketika } \\
\text { menyelesaikan soal LKS }\end{array}$ & 4 & 5 & 4,5 \\
\hline 5 & Beberapa siswa senang belajar kelompok & 4 & 5 & 4,5 \\
\hline 6 & $\begin{array}{l}\text { Siswa mampu mengungkapkan pemikiran } \\
\text { tentang materi yang yang dipelajari. }\end{array}$ & 4 & 4 & 5 \\
\hline 7 & $\begin{array}{l}\text { Siswa dalam kelompok mampu } \\
\text { mempresentasikan hasil diskusi di depan } \\
\text { kelas }\end{array}$ & 5 & 5 & 4,5 \\
\hline 8 & $\begin{array}{l}\text { Siswa di kelompok lain aktif menanggapi } \\
\text { hasil pekerjaan temannya }\end{array}$ & 5 & 4 & 4 \\
\hline 9 & $\begin{array}{l}\text { Siswa mampu bertanya ketika mendapat } \\
\text { kesulitan }\end{array}$ & 4 & 5 & 5 \\
\hline 10 & $\begin{array}{l}\text { Dengan bimbingan guru, siswa } \\
\text { menyimpulkan pembelajaran }\end{array}$ & 5 & $\mathbf{4 6}$ \\
\hline
\end{tabular}

Berdasarkan tabel 5, ketuntasan hasil observasi aktivitas siswa pada proses pembelajaran mencapai 92\%. Hasil observasi siswa ini meningkat sebesar 33\% dari siklus I. Hal ini menunjukkan bahwa indikator kerja dari segi proses sudah tercapai yaitu minimal $75 \%$.

Pada siklus II ini, pembelajaran dilakukan selama 2 pertemuan. Rangkaian selanjutnya pada tindakan ini adalah memberikan evaluasi atau tes siklus II secara perorangan, yang dilaksanakan pada hari Jum'at, 1 Desember 2017 setelah jam istirahat yaitu pukul 13.00 WIB. Tes ini bertujuan untuk mengetahui apakah terdapat kemajuan kemampuan berpikir kreatif siswa dari siklus I atau tidak setelah menggunakan pendekatan open ended.

Tabel 6. Hasil Analisis Ketuntasan Belajar pada Pembelajaran Siklus I

\begin{tabular}{cccc}
\hline No & Ketuntasan & Jumlah & Presentase \\
\hline 1 & Tuntas & 30 & $82,4 \%$ \\
\hline 2 & Tidak tuntas & 6 & $17,6 \%$ \\
\hline
\end{tabular}

Berdasarkan tabel 6, hasil evaluasi siklus II menunjukan bahwa hasil belajar melalui pengamatan kemampuan berpikir kreatif siswa mengalami peningkatan dari evaluasi siklus I, siswa yang memenuhi ketuntasan belajar sebanyak 28 siswa 82,4\% (memperoleh nilai > 70). Sedangkan ada 6 siswa atau 17,6\% yang belum memenuhi ketuntasan belajar dilihat dari kemampuan berpikir kreatif siswa.

Dari pengamatan yang dilakukan peneliti, keberhasilan hasil pelaksanaan tindakan siklus II dapat dilihat dua segi yaitu: Pertama, dari segi proses: pelaksanaan rencana pelaksanaan pembelajaran oleh guru telah mencapai indikator lebih dari $75 \%$. Kedua, dari segi hasil individu sudah mencapai indikator yang ditetapkan yakni $75 \%$ siswa memperoleh nilai lebih dari 70. Mengacu pada indikator kerja penelitian ini, dapat disimpulkan sudah tercapai.

\section{Refleksi}


Kegiatan refleksi pada siklus II menunjukkan siswa semakin aktif dalam mengemukakan pendapat, menyelesaikan soal latihan, dan kompak dalam bekerja bersama kelompoknya. Secara umum, kekurangan pada siklus I telah diperbaiki dengan baik pada siklus II.

Dari pengamatan yang dilakukan guru dan observer, hasil siklus II dapat dilihat dari dua segi: pertama dari segi proses: pelaksanaan rencana pembelajaran yang dilakukan guru telah memperoleh hasil $97 \%$ dan tindakan siswa memperoleh hasil 95\%. Hal tersebut melampaui indikator kerja yaitu tindakan guru dan siswa mencapai $80 \%$ sesuai dengan rencana pelaksanaan pembelajaran. Kemudian, yang kedua segi hasil: hasil belajar siswa pada siklus II mencapai $82,4 \%$ siswa yang mendapatkan nilai minimal 7.00 secara perorangan. Mengacu pada indikator kerja penelitian ini dapat disimpulkan sudah tercapai. Sehingga penelitian ini dilaksanakan sampai pada siklus II. Dengan demikian hipotesis tindakan penelitian ini telah tercapai bahwa kemampuan berpikir kreatif siswa kelas VIII-C SMP Darul Falah dalam materi persamaan linear dua variabel dapat ditingkatkan dengan menggunakan pendekatan open ended.

\section{Pembahasan}

Berdasarkan hasil observasi pelaksanaan pembelajaran matematika pada materi persamaan linear dua variabel untuk siklus I, menunjukkan bahwa penerapan pembelajaran menggunakan pendekatan open ended masih belum optimal. Ketika pengamat menganalisis tindakan guru dalam pembelajaran open ended, guru tidak memenuhi lima komponen open ended yang seharusnya terpenuhi pada setiap pertemuan. Sehingga, kebanyakan siswa masih keliru dalam menyusun dan menyelesaikan soal.

Dalam pembelajaran ini pengamat juga menganalisis perkembangan siswa. Secara umum pada siklus I, terdapat beberapa kekurangan yaitu siswa kurang menghargai dan menerima pendapat temannya ketika belajar berkelompok, siswa kurang berani dalam bertanya ketika mendapat kesulitan dalam belajarnya, dan siswa kurang optimal dalam memahami materi sehingga hasil tes siklus I indikator kerja tidak dapat terpenuhi.

Hasil tes siklus I menunjukkan bahwa hasil belajar yang diperoleh siswa mencapai 55,5\% atau 20 orang siswa yang mampu mendapat nilai tes minimal 7.00. Hal ini menunjukkan bahwa perolehan hasil evaluasi siswa belum mencapai indikator kerja yang ditetapkan. Ada beberapa hal yang menyebabkan tidak tercapainya hasil belajar siswa yaitu tindakan guru dan siswa pada siklus I memperoleh $65 \%$ dan 59\%. Hal tersebut belum mencapai indikator kerja yaitu $75 \%$ tindakan guru dan siswa sesuai dengan rencana pembelajaran.

Berdasarkan hasil observasi pada pelaksanaan tindakan untuk siklus II yang menerapkan pembelajaran menggunakan pendekatan open ended ini sudah lebih baik dari sebelumnya. Guru terus berupaya memperbaiki kelemahan yang ditemui dalam pelaksanaan tindakan siklus I. Guru sudah mampu mengontrol kegiatan siswa di kelas. Guru sudah mampu memotivasi siswa agar dapat belajar secara berkelompok, aktif dalam bertanya dan berpendapat, dan berani tampil depan teman-teman lainnya. Hal tersebut dapat mempengaruhi pada kemampuan berpikir kreatif siswa.

Dalam pembelajaran pada siklus II dilaksanakan dengan menggunakan pendekatan open ended agar kemampuan berpikir kreatif dapat lebih ditingkatkan lagi pada siklus kedua. Kelemahan guru pada siklus II. Namun, secara umum ketuntasan rencana pembelajaran yang dilakukan guru rata-rata mencapai $90 \%$. Hal ini karena guru sudah mampu melaksanakan pembelajaran dengan baik. Motivasi guru terhadap siswa cukup baik dengan perkembangan 
yang kontinu, agar siswa dapat aktif dalam bertanya dan berpendapat ketika pembelajaran berlangsung. Motivasi itu sendiri menurut Purwanto (Zanthy, 2016) adalah "pendorongan" suatu usaha yang disadari untuk mempengaruhi tingkah laku seseorang agar ia tergerak hatinya untuk bertindak melakukan sesuatu sehingga mencapai hasil atau tujuan tertentu. Selanjutnya guru sudah mampu mengikuti langkah-langkah pembelajaran yang terdapat dalam rencana pelaksanaan pembelajaran.

Berdasarkan hasil observasi pengamat terhadap pelaksanaan tindakan dalam rencana pembelajaran oleh guru pada siklus II telah mencapai indikator yang ditetapkan yaitu rata-rata ketuntasan mencapai ketuntasan tindakan siswa pada siklus II mencapai $92 \%$.

Kemudian, dengan melihat $92 \%$ dan skor yang diperoleh siswa, menunjukkan peningkatan hasil belajar siswa secara klasikal bila dibandingkan dengan hasil tes tindakan siklus I. Dari 36 siswa, yang mampu memperoleh nilai 70 ke atas mencapai $82,4 \%$ atau sebanyak 30 orang. Hal ini menunjukkan adanya peningkatan 26,90 atau sebanyak 8 siswa dari hasil tes tindakan siklus I. Berarti hanya $17,6 \%$ saja atau sebanyak 6 siswa yang masih mendapat nilai yang kurang dari 7.00. Di samping itu, hasil tes ini menunjukkan kemampuan berpikir kraetif matematika siswa tetap beragam yaitu cukup, baik, dan sangat baik.

Dengan demikian, siswa yang mampu menunjukkan kemampuan berpikir kreatif tentang materi persamaan linear dua variabel semakin bertambah dibandingkan dengan tes siklus I. Dengan kata lain, hasil tes siklus II menunjukkan bahwa prestasi siswa mengalami peningkatan bila dibandingkan dengan siklus I. Hal ini sesuai dengan pendapat Anni, dkk (Rahayu, Susanto, \& Yulianti, 2011) bahwa perubahan perilaku dalam belajar terjadi karena didahului oleh proses pengalaman.

Berdasarkan uraian di atas, maka dari segi perolehan hasil evaluasi siswa sudah mencapai indikator kerja yang ditetapkan. Demikian juga dengan ketuntasan rencana pembelajaran yang diterapkan guru telah mencapai indikator kerja dari segi proses.

\section{KESIMPULAN}

Berdasarkan hasil dan pembahasan, maka dapat disimpulkan bahwa kemampuan berpikir kreatif pada materi "persamaan linear dua variabel" kelas VIII-C SMP Darul Falah dapat ditingkatkan melalui pendekatan open ended. Hal tersebut diketahui dari banyaknya siswa yang mampu memahami materi dengan menemukan penyelesaian permasalahan dengan berbagai cara/alternatif berdasarkan pengalaman pembelajaran serta siswa mampu belajar dalam kelompok yang heterogen.

\section{UCAPAN TERIMA KASIH}

Kami ucapkan terimakasih kepada pihak yang terkait pada penelitian ini hingga dapat tersusunnya laporan hasil penelitian ini. Kepada pimpinan IKIP Siliwangi, dosen pembimbing, serta pihak SMP Darul Falah yang telah memberikan kesempatan dan fasilitas kepada peneliti selama melakukan penelitian.

\section{DAFTAR PUSTAKA}

Afandi, A. (2013). Pendekatan Open-ended dan Inkuiri Terbimbing ditinjau dari Kemampuan Pemecahan Masalah dan Representasi Multipel Matematis. Pythagoras: Jurnal Pendidikan Matematika, 8(1), 1-11. Retrieved from 
914 Anggraeni, Hendriana, \& Zanthy, Kemampuan Berpikir Kreatif Siswa SMP Kelas...

https://journal.uny.ac.id/index.php/pythagoras/article/view/8489/7002

Hendriana, H. (2014). Membangun Kepercayaan Diri Siswa Melalui Pembelajaran Matematika Humanis. Pengajaran MIPA, 19, 52-60.

Hidayat, W., Herdiman, I., Aripin, U., Yuliani, A., \& Maya, R. (2018). Adversity Quotient (AQ) dan Penalaran Kreatif Matematis Mahasiswa Calon Guru. Jurnal Elemen, 4(2), 230-242.

Istianah, E. (2013). Meningkatkan Kemampuan Berpikir Kritis dan Kreatif Matematik dengan Pendekatan Model Eliciting Activities (MEAs) pada Siswa SMA. Infinity, 2(1), 43-54. https://doi.org/https://doi.org/10.22460/infinity.v2i1.23

Karneli, R., Ananta, H., \& Hapsari, A. K. (2015). PENERAPAN MODEL COOPERATIVE SCRIPT DALAM PEMBELAJARAN MENGOLAH INFORMASI, 16(3), 20-24.

Rahayu, E., Susanto, H., \& Yulianti, D. (2011). Pembelajaran Sains Dengan Pendekatan Keterampilan Proses Untuk Meningkatkan Hasil Belajar Dan Kemampuan Berpikir Kreatif Siswa. Jurnal Pendidikan Fisika Indonesia, 7, 106-110. https://doi.org/10.15294/JPFI.V7I2.1081

Ristiani, R., Ratu, N., \& Prihatnami, E. (2014). identifikasi tingkat berpikir kreatif siswa dalam memecahkan masalah matematika melalui tipe soal Open Ended pada materi pecahan kelas, 1 18.

Setiawan, R. H., \& Harta, I. (2014). Pengaruh pendekatan open-ended dan pendekatan kontekstual terhadap kemampuan pemecahan masalah dan sikap siswa terhadap matematika. Jurnal Riset Pendidikan Matematika, 1(2), 241. https://doi.org/10.21831/jrpm.v1i2.2679

Taniredja, T., Pujiati, I., \& Nyata. (2010). Penelitian tindakan kelas. Bandung: ALFABETA.

Zanthy, L. S. (2016). Pengaruh Motivasi Belajar Ditinjau dari Latar Belakang Pilihan Jurusan Terhadap Kemampuan Berpikir Kritis Mahasiswa di STKIP Siliwangi Bandung. Teorema, 1(1).

Zanthy, L. S. (2018). K ontribusi Resiliensi Matematis Terhadap Kemampuan Akademik Mahasiswa pada Mata Kuliah Statistika Matematika, 7(1), 85-94. 